\title{
Versicherungs-Statistik
}

\section{für 1902}

\author{
über die
}

\section{unter Reichsaufsicht stehenden Unternehmungen.}

Hera us gege b e

vom

Kaiserlichen Aufsichtsamte für Privatversicherung.

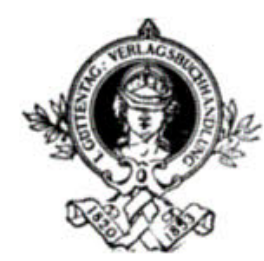

Berlin 1905.

J. Guttentag, Verlagsbuchhandlung, G. m. b. H. . 
